\title{
Stable carbon and nitrogen isotope ratios of surface food residues in pre-Columbian ceramics from the southern Pacific region of Costa Rica as evidence of prehistoric human diets
}

\author{
Maureen Sánchez P. ${ }^{1}$, Sally P. Horn ${ }^{2 *}$ \& Chad S. Lane ${ }^{3}$ \\ 1. University of Costa Rica, Ciudad Universitaria, School of Anthropology, Costa Rica; maureensanchezp@gmail.com \\ 2. University of Tennessee, Department of Geography, Knoxville, TN 37996-0925, USA; shorn@utk.edu \\ 3. University of North Carolina Wilmington, Department of Earth and Ocean Sciences, Wilmington, NC 28403-5944; lanec@uncw.edu \\ * Correspondence author
}

Received 28-VII-2018 • Corrected 18-IX-2018 • Accepted 07-X-2018

\begin{abstract}
Introduction: to understand and interpret the consumption of plants and animals by humans in the past requires the investigation of different lines of evidence. Identifiable macroscopic remains of plants and animals, for example seeds and bones, are frequently found at archaeological sites and provide key data on food resources. Their analysis is complemented by the study of pollen grains or phytoliths of cultivated plants within archaeological horizons or in sediment cores recovered from lakes and wetlands near archaeological sites. Another important source of information on human diets in the past consists of food residues preserved in or on artefacts excavated from archaeological sites. Objective: to examine food residues in archaeological pottery from coastal and interior sites in the southern Pacific region of Costa Rica. Methods: we focus on isotopic analysis of carbonized food residues preserved on the inner surfaces of ceramic pots, plates, and other ceramic pieces from archaeological excavations in the intermediate zone (elevations $500-1500 \mathrm{~m}$ ) and coastal zone of the southern Pacific region of Costa Rica. Isotopic analysis of surface food residues on pottery relies on the fact that stable isotopes of carbon $\left({ }^{12} \mathrm{C}\right.$ and $\left.{ }^{13} \mathrm{C}\right)$ and nitrogen $\left({ }^{14} \mathrm{~N}\right.$ and $\left.{ }^{15} \mathrm{~N}\right)$ in foods differ based on the photosynthetic pathway of plants and on trophic level. Results: in our analysis of material from twelve sites we found evidence of diets with high amounts of $\mathrm{C}_{4}$ plants (likely maize), legumes, herbivores, and mixtures, but we did not find robust evidence of food residues with isotopic signatures characteristic of reef animals and mollusks, even though some sites are shell mounds. Conclusion: our research represents one of the first studies of surface food residues from Costa Rican pottery, and indicates the potential for studies of this type to strengthen understanding of indigenous subsistence patterns through time and across Costa Rican archaeological regions.
\end{abstract}

Key words: Archaeology, food residues, maize, prehistoric diets, pottery, stable isotopes, southern Pacific Costa Rica.
RESUMEN: "Cociente de isótopos estables de carbono y nitrógeno de residuos alimentarios superficiales en cerámica precolombina del Pacífico sur de Costa Rica como evidencia de alimentación humana prehistórica". Introducción: para comprender e interpretar el consumo de plantas y animales por humanos en el pasado se requiere investigar diversas líneas de evidencia. Los restos macroscópicos identificables de plantas y animales, por ejemplo, semillas y huesos, se encuentran con frecuencia en los sitios arqueológicos y proporcionan datos clave sobre los recursos alimenticios. Su análisis se complementa con el estudio de granos de polen o fitolitos de plantas cultivadas dentro de horizontes arqueológicos o en núcleos de sedimentos recuperados de lagos y humedales cerca de sitios arqueológicos. Otra fuente importante de información sobre dietas humanas en el pasado consiste en residuos de alimentos preservados en o sobre artefactos excavados en sitios arqueológicos. Objetivo: examinar los residuos de comida en alfarería arqueológica de los sitios costero e interior del sureste pacífico de Costa Rica. Métodos: nos enfocamos en el análisis isotópico de residuos de alimentos carbonizados preservados en las superficies internas de ollas de cerámica, platos, y otras piezas de cerámica de excavaciones arqueológicas en las tierras intermedias (500-1500m) y en la zona costera de la región del Pacífico sur de Costa Rica. El análisis isotópico de residuos de alimentos superficiales en alfarería se basa en el hecho de que los isótopos estables de carbono $\left({ }^{12} \mathrm{C}\right.$ y $\left.{ }^{13} \mathrm{C}\right)$ y nitrógeno $\left({ }^{14} \mathrm{~N}\right.$ y $\left.{ }^{15} \mathrm{~N}\right)$ en alimentos difieren según la ruta fotosintética de las plantas y el nivel trófico. Resultados: en nuestro análisis de material de doce sitios arqueológicos encontramos evidencia de dietas con altas cantidades de plantas $C_{4}$ (probablemente maíz), leguminosas, herbívoros, y mezclas, pero no encontramos evidencia robusta de residuos de alimentos con firmas isotópicas características de animales de arrecife y moluscos, no obstante que algunos sitios fueron concheros. Conclusión: nuestra investigación constituye uno de los primeros estudios de residuos de alimentos de superficie de la cerámica de Costa Rica, e indica el potencial de los estudios de este tipo para fortalecer la comprensión de los patrones de subsistencia indígenas a lo largo del tiempo y a través de las regiones arqueológicas de Costa Rica.

Palabras clave: Arqueología, residuos de alimentos, maíz, dietas prehistóricas, alfarería, isótopos estables, Pacífico Sur de Costa Rica. 
The southern Pacific region of Costa Rica comprises landscapes of extraordinary environmental diversity, with coastal environments, islands, and large alluvial valleys bounded by mountain ridges that cross the territory in different directions. These landscapes have been occupied since $1500 \mathrm{BCE}$ by people who developed practices of marine harvesting, fishing in the ocean and inland waters, hunting, and later the cultivation of crops, becoming specialized farmers in early times (Corrales, 2000; Sánchez \& Rojas, 2002; Anchukaitis \& Horn, 2005; Horn, 2006; Baldi, 2011; Sánchez, 2013).

To understand and interpret the consumption of plants and animals in the past requires the investigation of diverse lines of evidence. Identifiable macroscopic remains of plants and animals, for example seeds and bones, are often found at archaeological sites and provide key data on food resources. Their analysis is complemented by the study of pollen grains or phytoliths of cultivated plants within archaeological horizons (Bryant \& Holloway, 1983; Piperno, 2006), or in sediment cores recovered from lakes and wetlands near archaeological sites (Northrop \& Horn, 1996; Clement \& Horn, 2001; Horn, 2006; Kennedy $\&$ Horn, 2008). Another important source of information on human diets in the past consists of food residues preserved in or on artefacts excavated from archaeological sites (Heron \& Evershed, 1993).

Here we focus on isotopic analyses of carbonized food residues preserved on the inner surfaces of ceramic pots, plates, and other earthenware from the southern Pacific region of Costa Rica. Our study represents the first comparative analysis of surface food residues from Costa Rican pottery and indicates the potential for studies of this type to strengthen our understanding of indigenous subsistence patterns through time and across Costa Rican archaeological regions.

Some additional analyses of the isotopic composition of food residues in Costa Rican pottery from individual sites were presented at the XI Congreso de la Red Centroamericana de Antropologia, held at the University of Costa Rica in March 2017, in a session on the analysis of stable isotopes in archaeology organized by Sánchez and Horn. These other analyses, as yet unpublished, grew from the present study; they are collaborations that also involve Horn and Lane, with University of Tennessee Ph.D. candidate Matthew Kerr, and Costa Rican archaeologists. Other studies of stable isotopes in Costa Rica with application to archaeology include work on stable carbon and nitrogen isotopes in collagen in human bones from prehistoric burials (Norr, 1991, 1996), and studies of stable carbon and nitrogen isotopes in lake-sediment cores (Lane, Horn, \& Mora, 2004; Lane, Horn, Taylor, \&
Mora, 2009; Taylor, Horn, \& Finkelstein, 2013, 2015; Kerr, 2014; Horn \& Haberyan, 2016; Johanson, 2016) and soils (Kerr, Boehm, Lane, \& Horn, 2014) at archaeological sites.

Isotopic analysis of surface food residues on pottery relies on the fact that the ratios of heavy to light stable isotopes of carbon $\left({ }^{13} \mathrm{C}\right.$ vs. $\left.{ }^{12} \mathrm{C}\right)$ and nitrogen $\left({ }^{15} \mathrm{~N}\right.$ vs. $\left.{ }^{14} \mathrm{~N}\right)$ in potential foods differ. To convert these ratios into large, whole numbers and for comparability between studies, carbon and nitrogen isotope values are reported in $\delta$-per mille notation relative to standards. Plants that photosynthesize using the $C_{3}$ photosynthetic process (all trees and most species of shrubs, herbs, and vines in Costa Rica) produce plant tissue with lower (more negative) $\delta^{13} \mathrm{C}$ values (-35 to $-20 \%$ ) than plants that photosynthesize using the $C_{4}$ pathway (maize and other grasses, and several agricultural weeds), which are relatively enriched in ${ }^{13} \mathrm{C}(-14$ to $-10 \%$ o) (Bender, 1971; O'Leary, 1981). Plants that are associated with nitrogen-fixing bacteria (beans and other legumes) have $\delta^{15} \mathrm{~N}$ values similar to the atmosphere $(\sim 0 \%)$, while other plants typically have higher $\delta^{15} \mathrm{~N}$ values (>2\%o; Morton \& Schwarcz, 2004). Nitrogen isotope signatures in animals are affected by trophic level, with each increase in trophic level associated with a 1 or $2 \%$ increase in $\delta^{15} \mathrm{~N}$ values (Peterson \& Fry, 1987; Heron \& Evershed, 1993). Stable carbon isotope values in animals are similar to that of their collective diet, but are sometimes slightly enriched in ${ }^{13} \mathrm{C}$ compared to their diet (Morton \& Schwarcz, 2004).

Hastorf and DeNiro (1985) and DeNiro (1987) were the first to investigate the stable isotope compositions of carbonized residues in ceramics as a method for characterizing plant foods prepared and eaten in prehistory. Working with pottery from the Upper Mantaro Valley in the central Peruvian Andes, they showed it was possible to use $\delta^{13} \mathrm{C}$ and $\delta^{15} \mathrm{~N}$ in charred residues to identify three groups of plants: leguminous $C_{3}$ plants (beans), non-leguminous $\mathrm{C}_{3}$ plants (quinoa or tubers), and $\mathrm{C}_{4}$ plants (maize) (Hastorf \& DeNiro, 1985). To develop and confirm their method, they investigated $\delta^{13} \mathrm{C}$ and $\delta^{15} \mathrm{~N}$ values in modern crops and carried out laboratory analyses of the effects of burning on isotope ratios and their stability. They found that when a plant is burned onto a ceramic pot the $\delta^{13} \mathrm{C}$ and $\delta^{15} \mathrm{~N}$ values of the residues were within $3 \%$ of their original values. They also demonstrated that the process of carbonization in some way stabilizes the plant residues, preventing further isotopic change following burial (DeNiro \& Hastorf 1985; DeNiro 1987).

Morton and Schwarcz (2004) examined food residues in ceramics from Ontario, Canada. They identified isotopic signatures of animal as well as plant foods in carbonized residues. Their samples were from both before and 
after $600 \mathrm{CE}$, the time of the introduction of agriculture, largely maize-based, to the region. Most of the residue samples reflected a mixture of $\mathrm{C}_{3}$ plants and the flesh of herbivores and fish. Only a low importance of maize was found in the post- $600 \mathrm{CE}$ samples, and the researchers speculated that the $\delta^{13} \mathrm{C}$ values in the food residue could be from the meat of animals (such as dog or bear) that had fed on maize, rather than the preparation of maize. No post-agricultural shift in $\delta^{15} \mathrm{~N}$ was apparent following the initiation of agriculture, showing low importance of beans; however, fish were an important protein source both before and after the introduction of agriculture.

Hart, Lovis, Schulenberg and Urquhart (2007) carried out laboratory simulations to test whether the low $\delta^{13} \mathrm{C}$ values in the post-agricultural pottery from Ontario might have another explanation. In a series of experiments they demonstrated a nonlinear relationship between the amount of maize cooked in a pot and the $\delta^{13} \mathrm{C}$ values of the residue. They suggested that Morton and Schwarcz (2004) may have underestimated the importance of maize at their sites, and that stable isotope analyses of food residues should be not be used in isolation to infer paleodiet.

A second study by Craig et al. (2007) echoed the theme of the Hart et al. (2007) study by referring to stable carbon isotope analysis of charred food residues as a "blunt tool" for distinguishing complex mixtures of food. Craig and collaborators supplemented stable carbon and nitrogen analyses of food residues in pots from coastal and inland sites in NW Europe with structural and molecular analyses of extracted lipids, to chart possible dietary changes following the adoption of agriculture. They were able to show that pots from both the Mesolithic and Neolithic were used to process aquatic organisms, demonstrating continued reliance on fish during the agricultural period.

The objective of our research was to examine food residues in archaeological pottery from coastal and interior sites in the southern Pacific region of Costa Rica. Our study, the first in the country comparing residues from multiple sites and time periods, complements archaeological and paleoecological research in the region, and sets the stage for later, more specialized analyses of food residues, including characterization of a variety of lipids and other specific compounds that can be extracted from visible or absorbed remains on/in ancient pottery (Hall, Tarka, Hurst, Stuart, \& Adams, 1990; Reber \& Evershed, 2004; Reber, Dudd, Van der Merwe, \& Evershed, 2004; Reber \& Hart, 2008; Hurst, 2009; Crown, Emerson, Gu, Hurst, Pauketat, \& Ward, 2012). Here we report the stable carbon and nitrogen isotope ratios in charred food residues from prehistoric (and one historic) ceramic vessels from diverse contexts, and interpret the results in light of archaeological, historical, and paleoenvironmental evidence from the sites and their surroundings.

\section{MATERIALS AND METHODS}

The School of Anthropology at the University of Costa Rica has investigated several archaeological sites in the southern Pacific region of Costa Rica (Fig. 1). For this study, we sampled charred food residues adhered to the surface of thirteen ceramic vessels from six archaeological sites.

Twelve of the thirteen samples are prehistoric pottery vessels that range chronologically from 700 to $1500 \mathrm{AD}$ (Table 1). One sample comes from a colonial site and corresponds to the period from 1571 to 1660 AD. Most of the samples came from defined contexts and were recovered in controlled excavations; however, to enlarge the data set a few vessels from surface reconnaissance were included.

The material selected for analysis is associated with varied environments that characterize the southern Pacific zone: coastal sites (Alto Purruja), piedmont (EI Cafetal), alluvial valleys (Iglesia de Guadalupe), savannas (Los Altos), and mountain ridges (Gamboa, Juan Vega, and Manchuria). The functionality of the selected sites corresponds to households at Los Altos, Gamboa, Juan Vega and El Cafetal. Alto Purruja is a coastal site associated with the consumption of resources from shoreline and offshore habitats. The Iglesia de Guadalupe is a colonial seat of the Spanish crown, where a church was constructed that controlled the indigenous population.

Analysis of charred pottery residues followed the protocol of Morton and Schwarcz (2004). Pottery residues were removed from potsherds by manually scraping with a spatula. All residue particles were then rinsed with distilled water three times to remove any adhering soil or other organic contaminants. The rinsed samples were then soaked in a $0,1 \mathrm{~N} \mathrm{NaOH}$ solution at $20^{\circ} \mathrm{C}$ overnight to remove humic acids. Minimal discoloration of the $\mathrm{NaOH}$ solution for all samples indicated minor humic acid contamination potential. All samples were then dried at $50^{\circ} \mathrm{C}$ overnight, ground to a fine powder using a mortar and pestle, and loaded into Sn capsules for isotopic analysis on a Costech 4010 Elemental Analyzer coupled to a Thermo-Finnigan XL+ Mass Spectrometer. Carbon and nitrogen isotopic data are reported in the delta $(\delta)$ per mille $(\% \circ)$ notation that relates to the Vienna Pee Dee belemnite (VPDB) and atmospheric nitrogen (AIR) standards, respectively, using the equation: $\delta X=$ $\left.1000^{*}\left[\left(R_{\text {sample }} / R_{\text {standard }}\right)-1\right)\right]$, where $X$ represents ${ }^{13} \mathrm{C}$ or ${ }^{15} \mathrm{~N}$, 


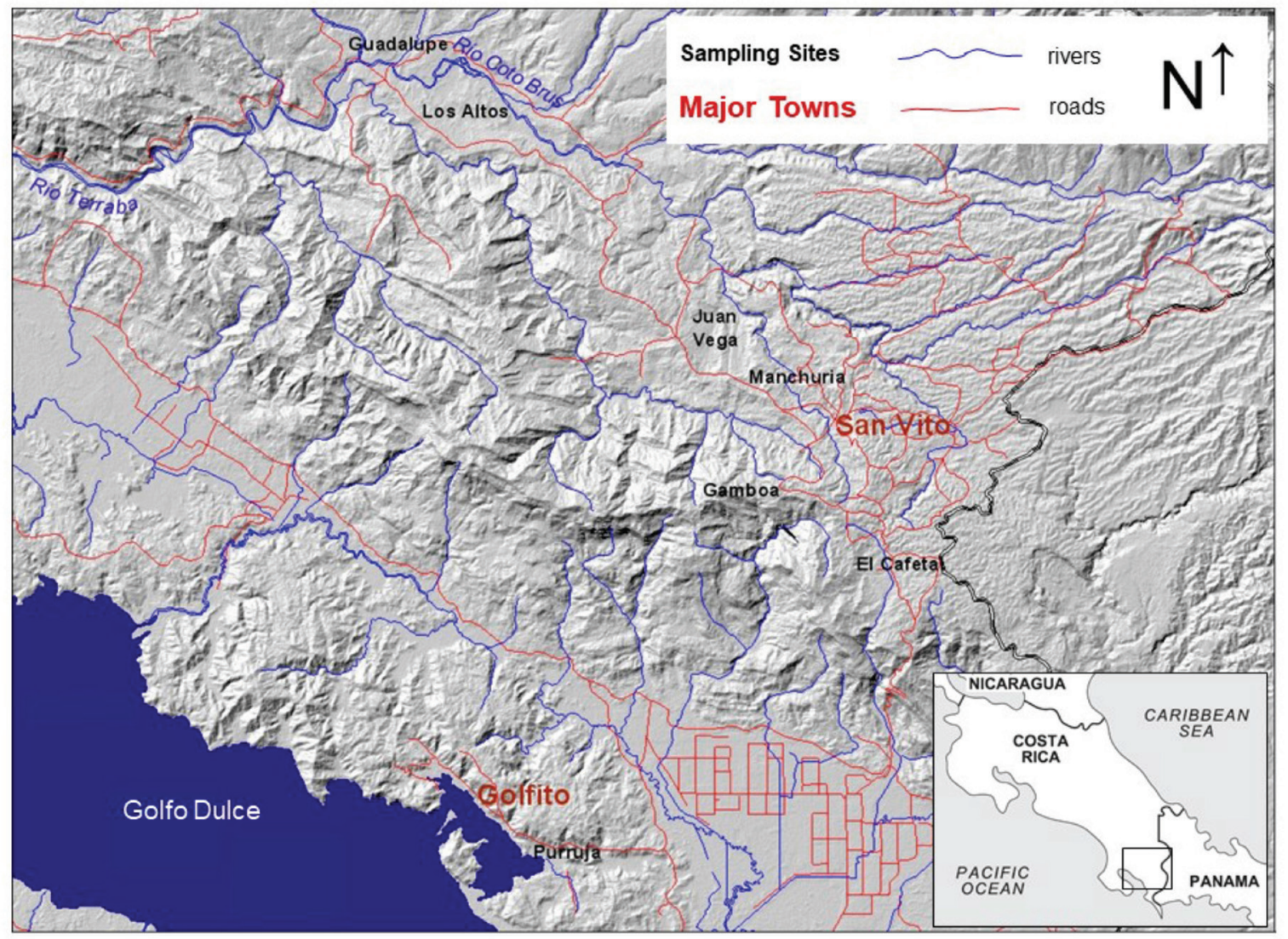

Fig. 1. Locations of archaeological sites in southern Pacific Costa Rica selected for the study of stable isotopes of food residues in ceramics. Purruja refers to the site Alto Purruja. Guadalupe refers to the Iglesia de Guadalupe.

TABLE 1

Material Selected for Analysis

\begin{tabular}{|c|c|c|c|c|}
\hline $\begin{array}{l}\text { Sample } \\
\text { Number }\end{array}$ & Site & Source of Material & Age & Reference \\
\hline 1 & Los Altos & $\begin{array}{l}\text { Sample from surface of. Mound XXV, } \\
\text { Quadrant C3 }\end{array}$ & Probably $1300-1500$ CE & Sánchez \& Novoa, 2005 \\
\hline 2 & Gamboa & Sample from test pit 16-N1 & Chiriquí Period (700-1500 CE) & Sánchez \& Rojas, 2002 \\
\hline 3 & Gamboa & Sample from test pit $1 \mathrm{~g} \mathrm{~N} 4$ & Chiriquí Period (700-1500 CE) & Sánchez \& Rojas, 2002 \\
\hline 4 & Gamboa & Sample from Surface A & Chiriquí Period (700-1500 CE) & Sánchez \& Rojas, 2002 \\
\hline 5 & Gamboa & Sample from Surface B & Chiriquí Period (700-1500 CE) & Sánchez \& Rojas, 2002 \\
\hline 6 & Alto Purruja & $\begin{array}{l}\text { Sample UCR-455 Op 3-S1-CB1 } \\
\text { from shell mound }\end{array}$ & Aguas Buenas Period probably $600 \mathrm{CE}$ & Rojas, 2000 \\
\hline 7 & Alto Purruja & $\begin{array}{l}\text { Test pit sample PZ1-4 from } \\
\text { shell mound }\end{array}$ & Aguas Buenas Period probably $600 \mathrm{CE}$ & Rojas, 2000 \\
\hline 8 & Manchuria & Surface sample P-653 Ma. & Chiriquí Period (700-1500 CE) & Sánchez \& Rojas, 2002 \\
\hline 9 & Juan Vega & $\begin{array}{l}\text { Sample from Profile UCR-495 } \\
\text { Op. } 4 \text { N3 }\end{array}$ & Chiriquí Period (700-1500 CE) & Chávez, 2000 \\
\hline 10 & El Cafetal & Sample from test pit $\mathrm{P}-642$ & Chiriquí Period (700-1500 CE) & Sánchez \& Rojas, 2002 \\
\hline 11 & El Cafetal & Sample from test pit P-642 & Probably $1300-1500$ CE & Sánchez \& Rojas, 2002 \\
\hline 12 & Alto Purruja & Sample 455-3-1-A2 & Aguas Buenas Period probably $600 \mathrm{CE}$ & Rojas, 2000 \\
\hline 13 & $\begin{array}{l}\text { Iglesia de } \\
\text { Guadalupe }\end{array}$ & $\begin{array}{l}\text { Surface sample of } 2 \text { fragments } \\
\text { of a ceramic vessel }\end{array}$ & Colonial (1571- $1660 \mathrm{CE})$ & Sánchez, 2013 \\
\hline
\end{tabular}


and $\mathrm{R}$ represents ${ }^{13} \mathrm{C} /{ }^{12} \mathrm{C}$ or ${ }^{15} \mathrm{~N} /{ }^{14} \mathrm{~N}$, respectively. Relative contributions of $C_{3}$ vs. $C_{4}$ plant-derived carbon to charred residues were estimated using the two end-member mixing model approach of Phillips and Gregg (2001) and assumed $\delta^{13} \mathrm{C}$ values of $-27 \%$ and $-12 \%$ or $C_{3}$ and $C_{4}$ plants, respectively.

Ethical, conflict of interest and financial statements: the authors declare that they have fully complied with all pertinent ethical and legal requirements, both during the study and in the production of the manuscript; that there are no conflicts of interest of any kind; that all financial sources are fully and clearly stated in the acknowledgements section; and that they fully agree with the final edited version of the article. A signed document has been filed in the journal archives.

\section{RESULTS}

The food residues analyzed reveal a wide variety in isotopic signatures (Fig. 2). The $\delta^{13} \mathrm{C}$ values of the residues range from $-24,9$ to $-10,5 \%$ and the $\delta{ }^{15} \mathrm{~N}$ values
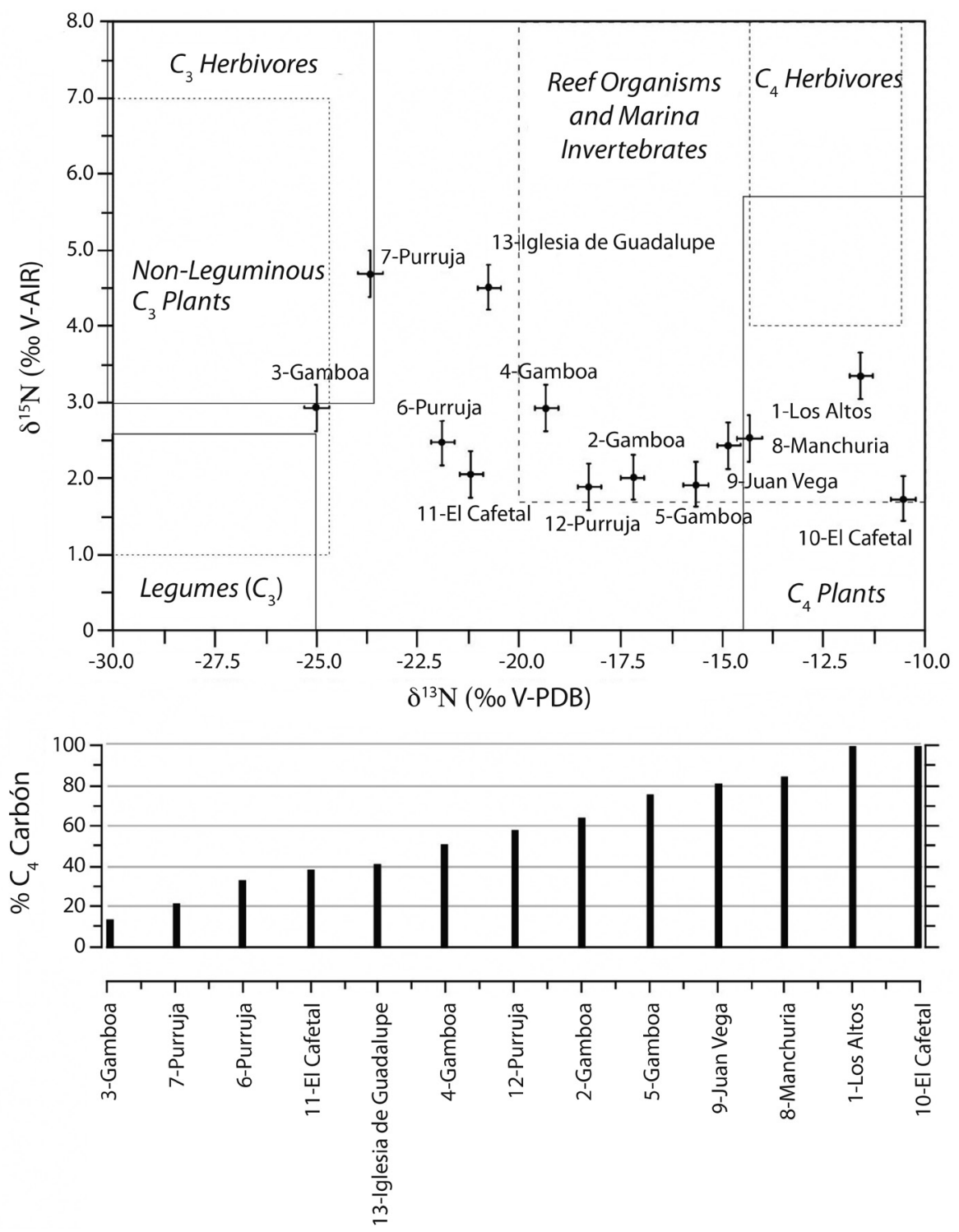

Fig. 2. Bivariate crossplot of pottery residue $\delta^{13} \mathrm{C}$ and $\delta^{15} \mathrm{~N}$ values for the pottery residues analyzed in this study (top panel). Boxes represent likely isotopic values of potential food resources in the region and are based on values presented in the literature (Keegan \& Deniro, 1998; Morton \& Schwarcz, 2004; Tykot, 2004). Parruja refers to the site Alto Purruja. Estimated C 4 plant contributions to the residues at each site (bottom panel) based on a two end-member mixing model applied to the $\delta^{13} \mathrm{C}$ values. 
range from 1,7 to 4,7\%o. Fig. 2 consists of two panels. In the upper panel, the 12 food residue samples are plotted by their $\delta^{13} \mathrm{C}$ and $\delta^{15} \mathrm{~N}$ values. The labeled boxes represent likely food resources and are based on values in the literature (Keegan \& Deniro, 1998; Morton \& Schwarcz, 2004; Tykot, 2004). The plotted positions of the samples relative to these boxes allow us to infer the composition of the food residue examined. A food residue sample could be composed of a single food source, in which case plotting the $\delta^{13} \mathrm{C}$ values against their $\delta^{15} \mathrm{~N}$ values should result in the sample falling within the individual box. Or, the food residue could consist of a mixture of food sources with different expected isotopic signatures. In that case, the sample will plot between boxes.

Application of the mixing model to the $\delta^{13} \mathrm{C}$ data yields $\mathrm{C}_{4}$ contributions to the residues ranging from 14 to 100\% (lower panel in Fig. 2), with the greatest apparent $\mathrm{C}_{4}$ plant contributions at El Cafetal and Los Altos and the lowest at Gamboa.

Stable isotope analysis of sample 1 from Los Altos yielded isotopic values that indicate that plant foods were exclusively from $\mathrm{C}_{4}$ plants, most likely maize. The $\delta^{15} \mathrm{~N}$ value falls slightly below the expected value for the flesh of herbivores that consumed $\mathrm{C}_{4}$ plants, but close enough to allow the possibility that the food residue analyzed contained maize along with meat from $\mathrm{C}_{4}$ herbivores.

The food residues in sample 2, 3, 4, and 5, all from the Gamboa site, showed some diversity in isotope signatures. The Gamboa site samples could potentially contain residues derived from reef or marine invertebrates, but they fall at the very low end of $\delta^{15} \mathrm{~N}$ values typical of higher trophic level (herbivorous and carnivorous) organisms typically consumed from these environments. More likely, values for sample 2 indicate a mixture of $C_{3}$ (most likely legumes) and $\mathrm{C}_{4}$ (maize), but mostly maize. Samples 3 indicates primarily $C_{3}$ plants, likely a mixture of legumes and other $C_{3}$ plants, and/or meat from $C_{3}$ herbivores. Sample 4 is split evenly between $C_{3}$ and $C_{4}$ plants. Sample 5 indicates a mixture of $C_{3}$ (most likely legumes) and $\mathrm{C}_{4}$ plants (maize), but mostly maize.

Food residue samples 6 and 7 were both collected from ceramics in shell mounds at the Alto Purruja site. Sample 6 indicates a mixture of $C_{3}$ (most likely legumes) and $\mathrm{C}_{4}$ (maize) plants, but mostly $\mathrm{C}_{3}$ sources. Plant foods in sample 7 are mainly from $C_{3}$ sources. In this sample, high $\delta^{15} \mathrm{~N}$ values indicate potential consumption of $C_{3}$ herbivores. Although these two samples of food residues were from pottery collected from shell mounds, the food residues do not show the high $\delta^{13} \mathrm{C}$ and high $\delta^{15} \mathrm{~N}$ endmember values typical for reef or marine invertebrates and just barely fall within expected values of organisms from these environments.

Samples 8 and 9, from pottery from the Juan Vega and Manchuria sites, show almost exclusive $C_{4}$ plant sources, likely maize. Sample 10, one of two food residue samples from the El Cafetal site, shows an exclusively $\mathrm{C}_{4}$ signature. Sample 11 , from the same site, is evenly mixed between $\mathrm{C}_{4}$ and $\mathrm{C}_{3}$ plants.

Sample 12, from a third piece of ceramic from the Alto Purruja site, shows an even split between $\mathrm{C}_{3}$ plants and $\mathrm{C}_{4}$ plants, and again no evidence reef or marine invertebrates. Sample 13, a food residue sample from the colonial church of Guadalupe, suggests a composition split between $\mathrm{C}_{3}$ and $\mathrm{C}_{4}$ plants, along with possible herbivore flesh as indicated by the high $\delta^{15} \mathrm{~N}$ values.

\section{DISCUSSION}

The identification of carbon isotopes in the selected samples allows us to conclude a consumption of $C_{4}$ plants (maize) along with legumes (beans) and other $\mathrm{C}_{3}$ plants. Archaeobotanical, ethnobotanical, and ethnographic studies in Costa Rica (Ibarra, 1990; Sánchez, 1992; Blanco \& Mora, 1994; Solórzano \& Quirós, 2006) indicate that $C_{3}$ plant foods other than legumes at these sites can include fruits, seeds, and shoots of palms (family Arecaceae) including Acrocomia vinifera (coyol) and Bactris gasipaes (pejibaye); fruits of Hymenaea coubaril (guapinol), Persea americana (avocado), Brysonima crassifolia (nance), Spondias sp. (jobo), Brosimum sp. (ojoche), Sechium edule (chayote), and other curcurbits (family Cucurbitaceae); Theobroma cacao (cacao) and other seeds; and a variety of tubers including Manihot esculenta (yuca), Ipomea batatas (camote), and Xanthosoma sagittifolium (malanga or tiquizque).

Our findings in all cases coincide with the geographical environment of the archaeological sites, which have suitable soil and climate conditions for the cultivation of plants detected in food residues. The very high $\delta^{13} \mathrm{C}$ values at several of our sites indicate a high reliance on maize during the Chiriquí phase, in keeping with archaeological and paleoecological evidence of maize in the region (Horn, 2006). The suggestion by Hart et al. (2007) that charred remains in pottery are likely to underestimate maize abundance makes our high values even more noteworthy.

The cases that indicate consumption of herbivorous animal-at the sites Gamboa, Alto Purruja, and the Iglesia de Guadalupe-indicate consumption of rodents such as tepezcuintle, or perhaps rabbit or tapir. At the 
Guadalupe church, a colonial settlement located on a wide alluvial terrace of the General River, the habitat suggests the possibility of whitetail deer, rabbit, rodents, and tapir. Here one can also think of the possibility of cattle introduced by the Spaniards.

It is important to keep in mind that these data do not reveal all of the plant or animal consumed by people who made and used the pottery fragments we studied. Rather, our data reveal the composition of burned foods stuck on pot bottoms. Foods prepared without cooking pots are not reflected in our data. Such foods might include fish or shellfish wrapped in leaves and put on a fire, meat cooked on sticks or a rock, or tubers buried under a fire. Similarly, foods cooked in a pot that did not burn to the bottom will also not be revealed by our isotopic analysis of food residues. The selective view of past diets provided by stable isotope analyses of burned food residues probably explains why none of the three samples collected from shell mounds at the Alto Purruja site showed strong evidence of marine or reef invertebrates.

This first broad look at the isotopic composition of food residues in Costa Rican ceramics from across the southern Pacific region sets the stage for more detailed future work at individual sites in this region, and in other regions of the country from which archaeologists have recovered earthenware with burned food residues. Future work might involve comparison of food residues in different households, potentially highlighting difference in diet by social status, or over time at sites of long occupation with well-dated samples. The latter study could potentially reveal shifts in food consumption brought about by cultural changes or shifts in climate. The study of the stable isotopic signatures of charred residues in cooking pots would be enhanced by obtaining AMS ${ }^{14} \mathrm{C}$ dates on charred residues, and by examining other potential proxies in the food residues, such as phytoliths (Staller \& Thompson, 2002; Thompson, 2006), and biomarkers (Hall et al., 1990; Heron \& Evershed, 1993; Evershed, 2008; Hurst, 2009; Reber \& Kerr, 2012). The study of food residues on pottery would be complemented by the paired study of residues from food and beverages absorbed within pottery and those in the associated burial matrix (Reber et al., 2004; Reber \& Kerr, 2012; Reber, Kerr, Whelton, \& Evershed, 2018).

\section{ACKNOWLEDGMENTS}

We thank Zachary Taylor and Greg Metcalf for assistance with sampling. Horn, Taylor, and Metcalf sampled ceramics selected by Sánchez in the Laboratory of Archaeology at the University of Costa Rica, while in the country for research funded by NSF grants \#0825406 to Horn and Taylor and \#0538420 to Horn, Orvis, and Champion. Zheng-Hua Li provided analytical assistance with stable isotope analyses, and Matthew Kerr and two anonymous reviewers provided suggestions that improved the manuscript.

\section{REFERENCES}

Anchukaitis, K.J., \& Horn, S.P. (2005). A 2000-year reconstruction of forest disturbance from southern Pacific Costa Rica. Palaeogeography, Palaeoclimatology, Palaeoecology, 221, 35-54. DOI: 10.1016/j.palaeo.2005.02.003

Baldi, N.F. (2011). Explotación temprana de recursos costeros en el sitio Black Creek (4000-2500 A.P.), Caribe Sur de Costa Rica. Revista de Arqueología Americana, 29, 85-121.

Bender, M.M. (1971). Variations in the $13 \mathrm{C} / 12 \mathrm{C}$ ratios of plants in relation to the pathway of photosynthetic carbon dioxide fixation. Phytochemistry, 10, 1239-1244. DOI: 10.1016/S0031-9422(00)84324-1

Blanco V., A., \& Mora. S.G. (1994). Plantas silvestres y cultivadas según la evidencia arqueobotánica en Costa Rica. Vínculos, 20, 53-77.

Bryant Jr., V.M., \& Holloway, R.G. (1983). The role of palynology in archaeology. In M. vB. Schiffer (Ed.), Advances in archaeological method and theory (Vol.6) (pp. 191-224). New York: Springer. DOI: 10.1016/B978-0-12-003106-1.50010-9.

Chávez, S. (2000). Subproyecto prospección y análisis sitio Juan Vega, UCR-495. Proyecto el potencial arqueológico en el Golfo Dulce, Pacífico Sur: Investigación-acción. Ciudad Universitaria, Costa Rica: Vicerrectoría de Investigación, Universidad de Costa Rica.

Clement R.M., \& Horn, S.P. (2001). Pre-Columbian land-use history in Costa Rica: a 3000-year record of forest clearance, agriculture and fires from Laguna Zoncho. The Holocene, 11,419-426. DOI: 10.1191/095968301678302850.

Corrales, F. (2000). An evaluation of long term cultural change in southern Central America (Doctoral dissertation). University of Kansas, Lawrence, Kansas, U.S.A.

Craig, O.E., Forster, M., Andersen, S.H., Koch, E., Crombe, P., Milner, N.J., ... Heron, C.P. (2007). Molecular and isotopic demonstration of the processing of aquatic products in northern European prehistoric pottery. Archaeometry, 49, 135-152. DOI: 10.1111/j.1475-4754.2007.00292.x

Crown, P.L., Emerson, T.E., Gu, J., Hurst, W.J., Pauketat, T.R., \& Ward, T. (2012). Ritual black drink consumption at Cahokia. PNAS, 109 (35), 13944-13949. DOI: 10.1073/ pnas. 1208404109

DeNiro, M.J. (1987). Stable isotopy and archaeology. American Scientist, 75(2), 182-191.

DeNiro, M.J., \& Hastorf, C.A. (1985). Alteration of ${ }^{15} \mathrm{~N} /{ }^{14} \mathrm{~N}$ and ${ }^{13} \mathrm{C} /{ }^{12} \mathrm{C}$ ratios of plant matter during the initial stages of 
diagenesis: Studies utilizing archaeological specimens from Peru. Geochimica et Cosmochimica Acta, 49, 97-115. DOI: 10.1016/0016-7037(85)90194-2

Evershed, R.P. (2008). Organic residue analysis in archaeology: the archaeological biomarker revolution. Archaeometry, 50, 895-924. DOI: 10.1111/j.1475-4754.2008.00446.x

Hall, G.D., Tarka Jr., S.M., Hurst, W.J., Stuart, D., \& Adams, R.E.W. (1990). Cacao residues in ancient Maya vessels from Rio Azul, Guatemala. American Antiquity, 55, 138-143. DOI: $10.2307 / 281499$

Hart, J.P., Lovis, W.A., Schulenberg, J.K, \& Urquhart, G.R. (2007). Paleodietary implications from stable carbon isotope analysis of experimental cooking residues. Journal of Archaeological Science, 34, 804-813. DOI: 10.1016/j. jas.2006.08.006

Hastorf, C.A., \& DeNiro, M.J. (1985). Reconstruction of prehistoric plant production and cooking practices by a new isotopic method. Nature, 315, 489-491. DOI: $10.1038 / 315489 \mathrm{a} 0$

Heron, C., \& Evershed, R.P. (1993). The analysis of organic residues and the study of pottery use. Archaeological Method and Theory, 5, 247-284.

Horn, S.P. (2006). Pre-Columbian maize agriculture in Costa Rica: Pollen and other evidence from lake and swamp sediments. In J. Staller, R. Tykot, \& B. Benz (Eds.), Histories of maize: Multidisciplinary approaches to the prehistory, biogeography, domestication, and evolution of maize (pp. 367-380). San Diego, California, USA: Elsevier Press.

Horn, S.P., \& Haberyan, K.A. (2016). Lakes of Costa Rica. In M. Kappelle (Ed.), Costa Rican ecosystems (pp. 656-682). Chicago, Illinois: The University of Chicago Press. DOI: 10.7208/chicago/9780226121642.003.0019

Hurst, W.J. (2009). The determination of cacao in samples of archaeological interest. In C. McNeil (Ed.), Chocolate in Mesoamerica (pp. 105-113). Gainesville, Florida: University of Florida Press. DOI: 10.5744/ florida/9780813029535.003.0005

Ibarra, E. (1990). Las sociedades cacicales de Costa Rica (Siglo XVI). San José, Costa Rica: Editorial de la Universidad de Costa Rica.

Johanson, E.N. (2016). Reconstructing Late Holocene fire, agriculture, and climate from sediment records in Costa Rica and the Dominican Republic (Doctoral dissertation). University of Tennessee, Knoxville, Tennessee, U.S.A.

Keegan, W.F., \& Deniro, M.J. (1998). Stable carbon- and nitrogen-isotope ratios of bone collagen used to study coral-reef and terrestrial components of prehistoric Bahamian diet. American Antiquity 53(2), 320-336. DOI: $10.2307 / 281022$

Kennedy, L.M., \& Horn, S.P. (2008). A Late Holocene poIlen and charcoal record from La Selva Biological Station, Costa Rica. Biotropica, 40(1), 11-19. DOI: 10.1111/j.1744-7429.2007.00334.x.
Kerr, M.T. (2014). Stable isotope analysis of lake sediments from Laguna Santa Elena and Laguna Azul, Costa Rica (master's thesis). University of Tennessee, Knoxville, Tennessee, U.S.A.

Kerr, M.T., Boehm, M.S., Lane, C.S., \& Horn, S.P. (2014). Report on loss-on-ignition, pollen, and stable carbon and nitrogen isotope analyses in soil samples from the Guayabo de Turrialba Site, Costa Rica. In G.M. Alarcón Z. (compiler). Informe proyecto arqueológico: Estudio de los límites espaciales y temporales del sitio arqueológico Guayabo de Turrialba (C-362 MNG). Segunda fase, Informe temporada 2013 (pp. 168-172). Ciudad Universitaria, Costa Rica: Facultad de Ciencias Sociales, Escuela de Antropología, Laboratorio de Arqueología, Universidad de Costa Rica.

Lane, C.S., Horn, S.P., \& Mora, C.I. (2004). Stable carbon isotope ratios in lake and swamp sediments as a proxy for prehistoric forest clearance and crop cultivation in the Neotropics. Journal of Paleolimnology, 32, 375-381. DOI: 10.1007/s10933-004-0259-x

Lane, C.S., Horn, S.P., Taylor, Z.P., \& Mora, C.I. (2009). Assessing the scale of prehistoric human impact in the neotropics using stable carbon isotope analyses of lake sediments: a test case from Costa Rica. Latin American Antiquity, 20(1), 120-133. DOI: 10.1017/S1045663500002546

Morton, J.D., \& Schwarcz, H.P. (2004). Palaeodietary implications from stable isotopic analysis of residues on prehistoric Ontario ceramics. Journal of Archaeological Science, 31, 503-517. DOI: 10.1016/j.jas.2003.10.001

Norr, L.C. (1991). Nutritional consequences of prehistoric subsistence strategies in lower Central America. (Doctoral dissertation). University of Illinois, Urbana-Champaign, Illinois, U.S.A.

Norr, L.C. (1996). Prehistoric coastal subsistence in northwestern Costa Rica: geographical diversity and chronological trends. In F. W. Lange (Ed.), Paths to Central American prehistory (pp. 253-269). Niwot, Colorado, U.S.A.: University Press of Colorado.

Northrop, L.A., \& Horn, S.P. (1996). PreColumbian agriculture and forest disturbance in Costa Rica: Paleoecological evidence from two lowland rainforest lakes. The Holocene, 6(3), 289-299. DOI: 10.1177/095968369600600304.

O'Leary, M.H. (1981). Carbon isotope fractionation in plants. Phytochemistry, 20, 553-567. DOI: 10.1016/0031-9422(81)85134-5

Peterson, B.J., \& Fry, B. (1987). Stable isotopes in ecosystem studies. Annual Review of Ecology and Systematics, 18, 293320. DOI: 10.1146/annurev.es.18.110187.001453

Phillips, D., \& Gregg, J. (2001). Uncertainty in source partitioning using stable isotopes. Oecologia, 127(2), 171-179. DOI: $10.1007 / \mathrm{s} 004420000578$

Piperno, D.R. (2006). Phytoliths: A comprehensive guide for archaeologists and paleoecologists. Lanham, Maryland, U.S.A.: Altamira Press. 
Reber, E.A., Dudd, S.N., Van der Merwe, N.J., \& Evershed, R.P. (2004). Direct detection of maize processing in archaeological pottery through compound-specific stable isotope analysis of $\mathrm{n}$-dotriacontanol in absorbed organic residues. Antiquity, 78(301), 682-691. DOI: 10.1017/ S0003598X00113316

Reber, E.A., \& Evershed, R.P. (2004). How did Mississippians prepare maize? The application of compound-specific carbon isotope analysis to absorbed pottery residues from several Mississippi valley sites. Archaeometry, 46(1), 1933. DOI: $10.1111 /$ j.1475-4754.2004.00141.x

Reber, E.A., \& Hart, J.P. (2008). Pine resins and pottery sealing: analysis of absorbed and visible pottery residues from central New York State. Archaeometry, 50(6), 999-1017. DOI: $10.1111 /$ j.1475-4754.2008.00387.x

Reber, E.A., \& Kerr, M.T. (2012). The persistence of caffeine in experimentally produced black drink residues. Journal of Archaeological Science, 39(7), 2312-2319. DOI: 10.1016/j. jas.2012.02.008

Reber, E.A., Kerr, M.T., Whelton, H.L., \& Evershed, R.P. (2018). Lipid residues from low-fired pottery. Archaeometry, 61(1), 131-144. DOI: 10.1111/arcm.12403

Rojas, P. (2000). Subproyecto excavación y análisis sitio Alto Purruja, UCR-455. Golfito. Proyecto el potencial arqueológico en el Golfo Dulce, Pacífico Sur: Investigación-acción. Ciudad Universitaria, Costa Rica: Vicerrectoría de Investigación, Universidad de Costa Rica.

Sánchez, M. (1992). Las sociedades antiguas en Costa Rica y la explotación de los recursos del bosque húmedo tropical. In M. Bolaños \& M. Sánchez (Eds.), Memoria del Seminario-Taller Prácticas Agrícolas Tradicionales: Un medio alternativo para el desarrollo rural centroamericano (pp. 19-30). San José, Costa Rica: Coproalde \& Universidad de Costa Rica.

Sánchez, M. (2013). Las sociedades de rango y su distribución territorial en el Pacífico Sur de Costa Rica. Revista de Arqueología Americana, 31, 59-80.
Sánchez, M., \& Novoa, V. (2005). Investigación arqueológica con fines académicos en el Sitio Los Altos P-655 La (CatUCR-517), Potrero Grande, Buenos Aires de Puntarenas, Informe de campo y laboratorio. Ciudad Universitaria, Costa Rica: Vicerrectoría de Investigación, Universidad de Costa Rica.

Sánchez, M., \& Rojas, P. (2002). Asentamientos humanos antiguos en las tierras intermedias del cantón de Coto Brus. Cuadernos de Antropología, 12, 87-106.

Solórzano, J.C., \& Quirós, C. (2006). Costa Rica en el siglo XVI: Descubrimiento, exploración y conquista. San José, Costa Rica: Editorial Universidad de Costa Rica.

Staller, J.E., \& Thompson, R.G. (2002). A multidisciplinary approach to understanding the initial introduction of maize into coastal Ecuador. Journal of Archaeological Science, 29, 33-50. DOI: 10.1006/jasc.2001.0750

Taylor, Z.P., Horn, S.P., \& Finkelstein, D.B. (2013). Pre-Hispanic agricultural decline prior to the Spanish conquest in southern Central America. Quaternary Science Reviews, 73, 196-200. DOI:10.1016/j.quascirev.2013.05.022

Taylor, Z.P., Horn, S.P., \& Finkelstein, D.B. (2015). Assessing intra-basin spatial variability in geochemical and isotopic signatures in the sediments of a small neotropical lake. Journal of Paleolimnology, 54(4), 395-411. DOI: 10.1007/ s10933-015-9859-x

Thompson, R.G. (2006). Documenting the presence of maize in Central and South American through phytolith analysis of food residues. In M. A. Zeder, D. G. Bradley, E. Emshwiller, \& B. D. Smith (Eds.), Documenting domestication: New genetic and archaeological paradigms (pp. 82-95). Berkeley, California, U.S.A.: University of California Press.

Tykot, R. (2004). Stable isotopes and diet: you are what you eat. In M. Martini, M. Milazzo, \& M. Piacentini (Eds.), Physics methods in archaeometry (pp. 433444). Bologna, Italy: Società Italiana de Fisica. DOI: 10.3254/978-1-61499-010-9-433 